Jusmal lemiah
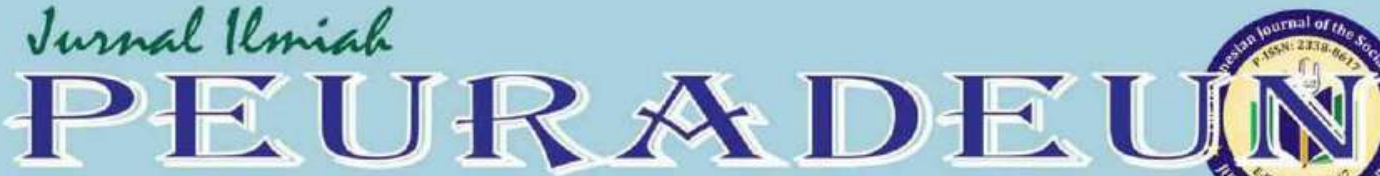

Vol. 6, No. 1, January 2018

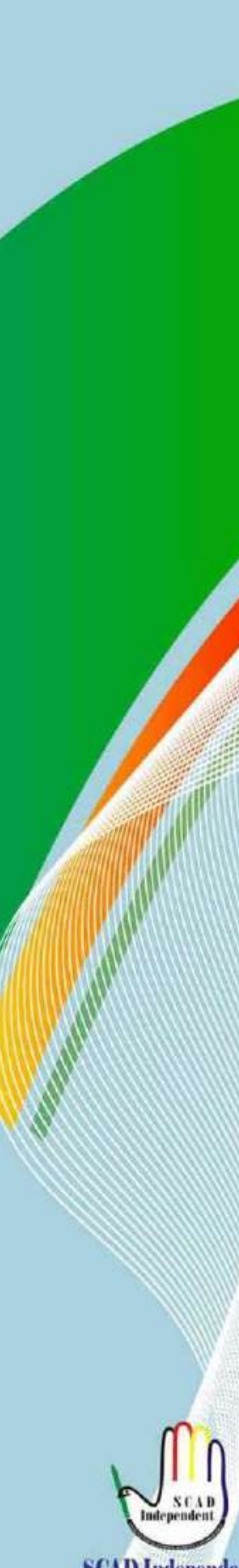

SCAI) Independent Accreditatioa by HO since 2014 $\bigodot$ Copernicus Publications

\section{III}

The Indonesian Journal of the Social Sciences www.journal.scadindependent.org Dot Prefix Number: 10.26811

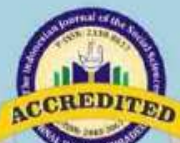

ACCREDITED - B" by the Ministry of Risteklikti from Oetaber 30, 2017 until Oetober 30, 2022

\section{Clarivate Analytics}

Emerging Sources Citation Index Web of Science ${ }^{\mathrm{TM}}$

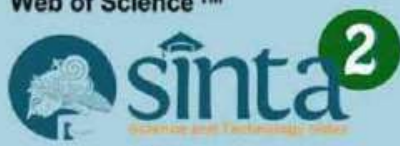
INDEX $\circledast$ COPERNICUS 


\title{
THE EFFECTIVENESS OF THE IMPLEMENTATION OF THE CASE METHODS IN THE LEARNING EVALUATION COURSE AT STATE ISLAMIC UNIVERSITY OF NORTH SUMATERA
}

\author{
Rusydi Ananda \\ Universitas Islam Negeri Sumatera Utara, Indonesia \\ Contibutor Email: rusdiananda.1972@gmail.com
}

\begin{abstract}
In the development of learning, it is very important to consider the characteristics of students to choose the appropriate approach in the learning activities. Teaching staff as the organizer of learning activities are required to seek the interaction of learners with other components of the learning system optimally. This research reveals about the efforts to improve student learning outcomes in the course by applying case study method strategy. The selection and application of learning strategy of the case method in learning course and learning Evaluation is conducted in accordance with the characteristics of the Learning Evaluation course itself which requires thinking skills and interaction skills from the students to understand the materials contained therein. The method used in this research is classroom action research. The results showed that the implementation of case study method strategy can improve learning outcomes in the course of Evaluation of Learning. This is evident from the increasing percentage of students in the eight aspects observed from both cycles carried out in the action of this study. This fact is supported by the result of $t$ test statistic test where obtained tct $=7,17$ while ttable price $=1,682$ so it can be interpreted that applying of case study method strategy can improve learning result of learning course lesson.
\end{abstract}

Keywords: Implementation, Case Method, Learning Evaluation, Learning Outcomes 


\section{A. Introduction}

Universities as institutions that provide higher education are responsible for giving provision to student with knowledge and skill needed to answer the challenge ahead. The university also produces science through research and serves as an intermediary for transfer, adaptation and dissemination of science found elsewhere, as well as supporting the government and the business world with its advice and consulting services. University also play an important role in the social field by realizing national identity and offering a forum of pluralistic debate but can be accounted for its scholarship.

Tilaar (2003) explained that the national education system as an organization must be dynamic, flexible so that it could absorb the changes that occur quickly, among others, due to the development of science and technology, the change of society towarded an increasingly democratic society and respected for human rights, all sources High learning power became a superior college. University was required to pay more attention to the needs of students and faculty as customers (customers) and (stakeholders) in a sustainable manner.

Decentralization of education offers a new paradigm for university managers to be more independent and develop all resources and potentials. These demands are expected to have implications for curriculum and university management. The change of education management becomes a necessity, so that university is required to change management so that their alumnus is really qualified as a manifestation of high accountability.

Various efforts within the framework of improving the quality of education in the educational institutions were managed by them. Efforts that have been done include improvements in the curriculum, rehabilitation and expansion of lecture buildings, laboratory provision, provision of practical equipment, procurement and improvement of professionalism of teaching staff. Although improvement efforts in all aspects of education have been done continuously, but there are obstacles and shortcomings. Among them are the achievements of academic value of students who have not reached the expected value. 
There are many factors that cause the low learning outcomes were obtained by students in learning, among others, as were stated by Hamalik (1993) that operationally there were five main variables that played a role in learning that also Rusydi Ananda gave influence to the achievement of learning result, namely: (1) the purpose Learning, (2) learning materials, (3) teaching methods and techniques, (4) teachers and (5) logistics. All of these variables were dependent on each other and could not stand alone in learning.

Not encouraging student learning outcomes allegedly because the less learning process supports student understanding, which is too much rote, less equipped with the capability of students. In these cases Wardiman (2001) disclosed a less supportive learning strategy, might not be in accordance with the subject matter, and might be too monotonous or less varied which might lead to not maximizing the acquisition of student learning outcomes.

In order to overcome the problem of the acquisition of the relatively low academic results, various efforts are made to improve students' understanding ability in the Learning Evaluation subject. One of effort that can be done is to improve the quality of learning with the application of better learning strategies. For that the ability of teachers to master learning technology to plan, design, implement and evaluate and do feedback becomes an important factor in order to achieve the learning objectives. Likewise, the ability of teachers to master learning materials, style of teaching, media use, strategy determination and selection of learning methods is an attempt to smooth the learning process and improve the achievement of goals.

lslameto (1995) stated that: in order for students to learn well the learning strategy should be tried as precisely, efficiently, effectively as possible. It was said to be effective when the learning strategy produced learning outcomes in accordance with the expected or in other words the goal was achieved. It was said to be efficient if the learning strategy was applied relatively using the effort, energy, cost and time was used to a minimum.

Learning strategy used by teachers during this time is not expected to be optimal, causing the boredom of the students who resulted in the 
low learning result. To reduce or even avoid a monotonous learning strategy, efforts are made to make more effective instructional strategies in creating multi-directional communication, so it is also expected to generate and enhance proactive interaction in learning. But be aware that the strategy is not the best or bad, because the strategy has advantages and disadvantages. As Sudjana (1989) disclosed that "every teaching method has advantages and weaknesses".

The selection of the right learning strategy is needed and must be adjusted to the characteristics of the Subject of Evaluation learning is quite solid then required the independence of students in finding other sources. Therefore, the characteristics of students are one of the components that must be considered carefully by the lecturers in identifying the ability of students that will help in determining the right materials, strategies, methods and right media to use. This needs to be done so that the lessons delivered can attract students' attention and every second that takes place in meaningful and non-boring learning activities.

This research reveals about efforts to improve student learning result in the subject by applying case study strategy as one of the learning strategies that can be applied to the learning. Selection and implementation of case study strategy in learning subject of Learning Evaluation is conducted in accordance with the characteristics of the Learning Evaluation subject itself which requires thinking skills and interaction skills from students to understand the materials contained therein.

Therefore the right strategy used is a case study method, where in case study method study is developed thinking ability, intellectual skill, interaction, and work together for problem solving and learn about various role by involving in real experience becomes independent student.

\section{B. Problem Formulation}

The intended research is classroom action research to improve, improve or change learning in Learning Evaluation course, so the problem of this research can be formulated as follows: (1) how is the application of learning strategy of case method in learning course of learning evaluating?, 
and (2) is there Improving learning outcomes Learning Evaluation course learned by case study method strategy?

\section{Theoretical Basis}

Learning strategy is a series of learning activities and the creation of student learning conditions actively. If the learning strategy can encourage the emergence of student activities then the learning process will also be more and more students will occur in turn later student learning results will increase.

Gagné and Briggs (1979) said that the instructional system was a set of events that affect learners so that the learning process occurs. A set of events that may be done by the teacher so that it is called learning, may also be done by students themselves by using books, pictures, television programs or a combination of various media, both teachers and by students themselves, the activity must be planned systematically to be called activities learning.

Dick and Carey (1996) said that learning strategies contain five main components: (1) preliminary learning activities, (2) information delivery, (3) student participation, (4) tests, and (5) follow-up activities. Suparman (2001) defines learning strategy as a combination of (1) instructional sequence; (2) ways of organizing teaching materials and students, (3) equipment and materials, and (4) time was spent in the learning process. Both definitions put forward by experts are in principle more emphasis on aspects of components and procedures of teaching.

Romizowski (1981) contended that learning strategy was a comprehensive approach that could be divided into two basic strategies, namely expository (explanation) and inquiry/ discovery (invention). Both of these strategies could be viewed as two ends that were aligned in one continuum of strategy. This was closely related to the deductive approach in which this strategy started with the presentation of information about principles or rules and then were followed by tests of mastery and application in the form of examples and application in certain situations, 
while the strategy of inquiry/ discovery was based on experiential learning theory was called also learning theory experience.

Hamalik (1993) defined learning strategy as an overall system consisting of a number of components, namely input component, process component and product component (output). Dimyati and Moedjiono (1999) explained that in order to optimize the interaction between learners and the components of other learning systems, the faculty must consist of each aspect of the components that made up the system and could do so with various strategies. The activities of the faculty seek consistency between the aspects of the components of the learning system with this particular strategy which was called learning strategy term.

Merill (1981) classified three basic learning strategies (1) teaching objectives covering ten combinations of material types and expected behavior, (2) how to present material from a specific level to a general level or vice versa from a general level to a level Specifically, and (3) the response form of learners is differentiated on expository and mercury strategies.

Romizowski (1981) stressed that every learning strategy always reflected the theoretical position hold on how the lesson should be implemented. Therefore, lecturers as the organizer of learning activities were expected to strive for the interaction of learners with other components of the learning system optimally.

Mudhoffir (1993) clarified the meaning of learning strategy slightly more broadly because it included also the meaning of the teaching approach in the delivery of information, selecting the supporting sources of teaching and determining and explaining the role of students in preparing the learning program that took into account the condition of the student environment so that learning became more effective.

Learning strategy can be classified into four meanings namely : the sequence of lesson activities, namely teaching activities in delivering the content of the lesson to learner, the method of learning, namely the way teacher organizes learning materials and learners to happen learning process effectively and efficiently, learning media is an equipment And learning 
materials used by teachers and learners in learning activities, and time spent by teachers and students in completing each step in the learning activities.

In using learning strategies the main point to note is the characteristics of students. Seels and Richey (1994) stated that the characteristics of learners were aspects of background experience that affected the effectiveness of the learning process.

Dick and Carey (1996) explained that in the development of learning it was really important to consider the characteristics of students to choose the appropriate approach in the learning activities. The steps taken as a learning design and development procedure were: (1) needed analysis to identify general learning objectives, (2) did instructional analysis, (3) analyzed student's characteristics and context, (4) development of assessment instruments, (5) Developed learning strategies, (6) developed and selected learning materials, (7) designed and compiled formative evaluation of learning, (8) designed and compiled summative evaluations of learning, and (9) revisions for each step of instructional development.

The development of learning strategies as mentioned has a foundation of learning theories and studying. The need for this theory, according to Snelbecker (1974), was (1) to systematize the results of research so that the first unknown phenomena could be understood, (2) the theory functioned to generate the hypothesis, thereby telling which direction the attention should be given and where it should be found the answers to emerging questions, (3) theory could be used to make a prediction, so that it was not only given the answers to current questions, but also showed what could be expected, and (4) theories could be used to explain the symptoms faced, Or in other word through the theory could be explained why something symptoms occur. Further it was explained that the learning theory was a set of principles integrated, which provided guidance to regulate the conditions to achieve the learning objectives.

Reigeluth (1983) described three main components of learning theory, namely: methods, conditions, and results. Teaching methods were a variety of ways to achieve a variety of results, in a variety of conditions. 
The teaching condition was a factor affecting the impact of the method. Teaching result were consequences that could be used to measure the usefulness of different methods under various conditions.

The learning using case method was spearheaded by the Harvard business school led by Dr. Copeland circa 1910. Christen and Hansen (1987) defined the case method was a partial, historical, clinical study of a situation that had confronted a practical administrator or managerial group. Presented in narrative form to encourage student involvement, provided substantial data and processes for analysis of a specific situation to form alternative work programs and for implementations that recognized the complexities and ambiguities of the practice world.

Leenders and Erskine (1978) defined the case method was an instructional method in which students and instructors participated in direct discussion of cases or problems that were usually prepared in written form and generated from real experience. Jogiyanto (2006) explained the case method tried to simulate real conditions into controllable environments in the classroom where discussions would be done place to understand the decision-making process to obtain result desired or unwanted result.

Learning by applying the case method has the following characteristics:

1. Emphasize on situational analysis.

The analysis of the specific situation makes students relate to what happened instead of what might happen. The goal or purpose of the ongoing discussion is to help students build their capacity to work under certain conditions.

2. The importance of linking between analysis and action.

In case study the method combines activities to know (to know) and activities to act (to act) in the form of product understanding what should be done and how to do it.

3. The need for student involvement.

Student involvement in emotional learning and intellectual learning is paramount in the success of case study learning. 
4. The role of non-traditional teacher.

Teachers accustomed to teaching by lecture methods will see learning by case method is a strange and incomprehensible learning. Why waste a lot of time asking a student if it can actually be used by a teacher to explain something.

5. Balance between substantial targets and learning process.

The case method will produce students who can understand abstract theories and knowledge and more importantly are able to apply these elements to real practice.

Corey (1976) described the elements in case study methodology: (1) discovery, (2) investigation, (3) continuous training, (4) differences and comparison, (5) engagement, and (6) motivation. Learning by invention was done in the classroom by providing a series of cases containing with facts, the task of the student was to collect data and information were provided in the learning activity to further interpret and discover its meaning. These was a process of discovery was made through quantitative analysis of collecting scattered data in cases and selecting them relevant to resolve issues. The process of the invention was also carried out from the results of other students' answered which might be considered correct or incorrect by other students.

Learning through investigation aims to improve students' ability to think sharply, use the evidence correctly, to recognize hidden assumptions and follow them to the end, thus implicating the important reasoning process of the students. Learning through ongoing training aims to hone student skills because they constantly practice in solving cases.

Learning with differences and benchmarks are to analyze differences and comparisons of different problem situations. Understanding why a solution can be done in situations and why it can not be done in different conditions or situations is a learning to raise awareness not to always generalize the problem. Learning through engagement is learning that encourages students to participate and engage in learning activities. Through learning through this engagement students receive a real experience. Learning through motivation is learning that is not forced 
but students does it consciously and with their own desires and strong motivation. Case studies if done well will generate excitement and excitement from students because they believe in getting something new and interesting.

The role of teachers in case study methods as explained by Christensen and Hansen (1987) are:

1. Teachers' duties not only teach (teach) students but more encourage students to learn (learning). This shift in goals will result in different teachers in preparing the materials, teaching in the classroom and how to measure learning outcomes.

2. The teacher must be able to abandon his old role and status as an intellectually better center-stage.

3. Teachers should be able to develop skills in observing, listening, communicating and making decisions so that learning is meaningful.

The benefits of case methods in learning activities are as follows:

1. Context of the real world.

Students can see how the course material is applied to the real world outside the classroom, so that by getting a real picture then the students will be motivated to learn.

2. Dig a lot of perspectives.

Cases that contain decisions to solve can be used to encourage students to see from multiple sources and see how many students can divert different decisions. Students can also learn how a decision will have an impact on different participants.

3. Requires critical thinking and analysis.

Case usually asks students to analyze data to reach conclusions. Since assignment in the case is usually open-ended, students can choose the most appropriate analytical technique.

4. Students synthesize the contents of the lecture.

Many cases require students to use analytic techniques and information from different courses to be able to provide effective solutions. 


\section{Research Methods}

The method used in this research is class action method. Selection of this method is based on an effort to improve the effectiveness of learning that takes place in the cycle stage that starts from planning, action, observation, reflection and return to planning for action. It is hoped that the practical problems of learning can be overcome, this is in line with Ebbut's expression in Wiriaatmadja (2005) which stated that: classroom action research was a systematic study of improving the implementation of educational practices by a group of teachers by taking actions in learning based on their reflection from the results of action -the action.

To realize these expectations, the action research is designed with a cyclical assessment process consisting of 4 (four) phases of activity: planning, performing, observing and reflecting. This stage continues to recur until a problem is considered resolved to be followed by the appearance of other problems that should also be treated similarly. The four phases of activity of an action research cycle are usually described by a spiral: planning, action, observation and reflective.

The subject of the research was the fourth semester student of Islamic education program of the academic year 2016-2017. The data collection tools in this study are observation/ field notes, and test of learning result. This research procedure is done through two cycles, in each cycle consists of planning, implementation, observation and reflection. Data analysis technique used is descriptive quantitative. Quantitative data obtained from the observation of the implementation of the next action is analyzed by narrating the test results in the form of frequency disturbs table. Furthermore, to test the action hypothesis that the researcher proposed is done by analyzing the learning outcomes in the first cycle with the learning outcomes in the second cycle by using the t-test value.

\section{E. Research Results and Discussion}

\section{Research Result}

Implementation of learning is done to focus on the emphasis of the ability of students in understanding the teaching materials with as 
attractive as possible so as to enable the occurrence of student learning activities which in turn can improve learning outcomes Learning Evaluation. The emphasis of the importance of application of case study method in course learning process of Learning Evaluation becomes very important to accelerate student understanding. In this case the learner applies his learning by emphasizing the application of case method. Furthermore, based on the observation of student activity in the learning process obtained student activity data as listed in Table 1 as follows:

Table 1 Student Activity during the Action Process

\begin{tabular}{|c|c|c|c|c|}
\hline \multirow{2}{*}{ Observation Category } & \multicolumn{2}{|c|}{ Cycle I } & \multicolumn{2}{c|}{ Cycle II } \\
\cline { 2 - 5 } & $\mathbf{F}$ & $\mathbf{\%}$ & $\mathbf{F}$ & $\mathbf{\%}$ \\
\hline 1 & 28 & 70,00 & 30 & 75,00 \\
\hline 2 & 3 & 7,50 & 5 & 12,50 \\
\hline 3 & 8 & 20,00 & 12 & 30,00 \\
\hline 4 & 4 & 10,00 & 7 & 17,50 \\
\hline 5 & 21 & 52,50 & 27 & 67,50 \\
\hline 6 & 18 & 45,00 & 25 & 62,50 \\
\hline 7 & 20 & 50,00 & 29 & 72,50 \\
\hline 8 & 30 & 75,00 & 33 & 82,50 \\
\hline
\end{tabular}

Information:

a. Pay attention to the teacher's explanation

b. Asking questions

c. Respond to the teacher's questions

d. Convey ideas/ opinions

e. Make a note/ resume on teaching materials

f. Eager to follow the learning activities

g. Be actively involved in learning activities

h. Do the task/ test independently

Based on the above table. It can be explained that during the observation in the first cycle, found several types of student activities of which is activity 1 (attention to the explanation of teachers) that is the dominant student learning activities compared with other activities. This can be explained because at the beginning of the teaching the teacher 
gives an explanation through the lecture. Furthermore activity 2 (asking only few students) another activity that looks more prominent is activity 7 (actively involved in learning activities). Then in activity 8 (do the task/ test independently), majority students mobilize the students who are given the teacher Independent.

In the second cycle can be seen changes in student activity behavior. Among these changes in category 3 (responding to teacher questions) experienced a significant increase. This is because students have received the results of the work cycle I distributed by the teacher at the beginning of the lesson. Many students ask about the material being studied. Category 4 (conveying ideas/ opinions) has increased significantly as well. This is because students are increasingly involved in learning activities that apply the learning strategy of case method. Category 6 (eagerly following the learning activities) and $7^{\text {th }}$ category (actively involved in simulation activities) also experienced a significant increase.

Students' learning result in the first cycle is measured by providing an essay test evaluation. The learning result obtained can be seen in Table 2 .

Table 2 Average Recapitulation of Student Learning Results In the First Cycle and the Second Cycle

\begin{tabular}{|c|c|c|c|}
\hline No & Cycle & Cumulative Value & Average Value \\
\hline 1 & First & 2590 & 64,75 \\
\hline 2 & Second & 2722 & 68,05 \\
\hline
\end{tabular}

Furthermore, to accept or reject the hypothesis of action that the researcher proposed that is through the learning strategy case method can improve student learning outcomes in course Learning Evaluation is done by analyzing the learning outcomes in the first cycle with the learning outcomes in the second cycle using t-test obtained $t_{\text {count }}=7,17$ while $t_{\text {table }}$ at $d k 39$ and $\alpha=0.05$ is 1.682 . Because the price of $t_{\text {count }}(7,17)>t_{\text {table }}$ price $(1,682)$ thus the action hypothesis that the researcher proposed that is through the learning strategy of case method can improve the learning result of the course Evaluation of Learning proved empirically correct. 


\section{Discussion}

The main task of teachers in learning activity is to design a conducive learning environment, help and facilitate students to achieve learning goals and the unforgettable is to balance the intellectual, emotional and spiritual growth of students. Therefore, teachers should be able to make it happen in every learning activity that take place in the classroom.

Learning Evaluation is one of the main subjects given to the students as the material that becomes the provision of teacher candidates. But can the daily learning activities, especially in the delivery of materials Evaluation Learning, students who are less interested, less motivated, even seem less interested in following. The lack of interest in students, less motivated, and less interested impression is actually happening when the learning is centered only on the teacher. Therefore the task of teaching designing learning interesting and varied.

Lessons Learned Learning lessons can be more interesting when teachers are able to plan better classroom management strategies. Good planning and management of teaching by the teacher can help teachers to improve their learning outcomes. Learning by using case method strategy was able to provide better learning outcomes. From the results of this study can be concluded that learning lesson Learning Evaluation method of learning strategy case can be used as an alternative teaching strategies that can be applied teachers.

Based on the observations obtained in the cycle I is the observation category 1 (attention to the teacher's explanation) of $70.0 \%$, the observation category 2 (ask questions) of $7.50 \%$, category 3 (responding to teacher questions) of $20.00 \%$, category 4 (Submitting ideas/ opinions) of $10.00 \%$, observation category 5 (making notes/ resume on teaching materials) of $52.50 \%$, observation category 6 (eagerly following learning activities) of $45.00 \%$, observation category 7 (involved Active in learning activities) of $50.00 \%$ and the observation category 8 (working on the task / test independently) of $75.00 \%$.

In cycle II there are some changes in student behavior. The change in question is generally a change to a better direction. These changes 
include the observation category 1 (attention to the teacher's explanation) increased to $75.00 \%$, the observation category 2 (ask questions) increased to $12.50 \%$, category 3 (responding to the teacher's question) increased to $30.00 \%$ Category 4 (convey ideas/ opinions) increased to $17.50 \%$, observation category 5 (made notes/ resume on teaching materials) increased to $67.50 \%$, observation category 6 (eagerly following learning activities) increased to $62,50 \%$, category of observation 7 (actively involved in learning activities) increased to $72.50 \%$ and the observation category 8 (working on the task/ test independently) increased to $82.50 \%$.

Finally, changes in teacher teaching behavior and changes in student learning behavior facilitated through action research have an impact on improving student learning outcomes, where the results of this study show that students achieve mastery learning, a situation that is difficult to achieve before. This phenomenon implies that learning by utilizing instructional strategies implemented by researchers, has the quality of process and the quality of good learning outcomes.

The result of research that has been presented in advance will provide a wider impact if other subjects' teachers, especially in the Faculty of Science Tarbiyah and Teacher Training UIN North Sumatra also innovate in learning through the implementation of innovative and creative learning strategies. One learning strategy is not always well applied to all studies and all teaching subjects, therefore teachers should continue to try and develop their creativity to design learning that is able to motivate students to learn.

\section{F. Conclusions}

Based on the results of research actions that have been done, it can be put forward the conclusion of researchers as follows: descriptively can be concluded, that the learning activities by applying the strategy of case study method can improve learning outcomes Learning Evaluation. This is evident from the increasing percentage of students in the eight aspects observed from both cycles carried out in the action of this study. The fact is supported by the result of $t$ test statistic test where obtained $t_{\text {count }}=7,17$ 
while $t_{\text {table }}$ price $=1,682$ so it can be interpreted that through applying of case study method strategy can improve learning result of course Learning Evaluation.

Furthermore, recommendations that can be given in connection with the results of this study are: (1) learning strategy case method can be used as an alternative in learning in Learning Evaluation lesson, (2) in the implementation of learning case method using relatively more time, the teacher must Pay attention to the use of time in planning and implementation, and (3) teachers are expected to be more creative in learning strategies so that students are interested and motivated to follow the lesson.

\section{Bibliography}

Bhebhe, G., \& Mugurani, M. (2016). Challenge Learning for Teachers in Rural Gweru Zimbabwe. Jurnal Ilmiah Peuradeun, 4(3), 295-308.

Christensen, C.R and Hansen, A.J. (1987). Teaching and the Case Method. Boston: Harvard Business School Publishing

Corey, E.R. (1980). Case Method Teaching. Boston: Harvard Business School Publishing

Dick, W. and Carey, L. (1996). The Systematic Design of Instruction. Fouth Edition. New York: Harper Collin College Publisher

Dimyati and Moedjiono. (1991). Strategi Belajar Mengajar (Suatu Tinjauan Pengantar). Jakarta:Dikti

Gagne, Robert M. and Briggs, L.J. (1979). Principles of Instructional Design. New York: Holt Rinehart and Winston

Hamalik, O. (1993). Strategi Belajar Mengajar. Jakarta: Bumi Aksara

Idris, S \& Tabrani, Z. A. (2017). Realitas Konsep Pendidikan Humanisme dalam Konteks Pendidikan Islam. Jurnal Edukasi: Jurnal Bimbingan Konseling, 3(1), 96-113.

Jogiyanto. (2006). Pembelajaran Metode Kasus. Yogyakarta: Andi Offset

Leenders, M.R and Erskine, J.A. (1978). Case Research. London: University of Ontario 
Merril, MD. (1981). A Lesson Based on the Component Display Theory. New Jersey: Lawrence Erlbaum Ass

Mudhoffir. (1993). Teknologi Instruksional. Bandung: Remaja Rosdakarya

Pomalingo, S. (2014). Perguruan Tinggi dan Transformasi Nilai-Nilai Islam dalam Konteks Sosial-Budaya Masyarakat Indonesia. Jurnal Ilmiah Peuradeun, 2(3), 119-134.

Rafida, T. (2017). The Determination of Effective Educational Institution at Undergraduate Program of North Sumatra State Islamic University. Jurnal Ilmiah Peuradeun, 5(2), 169-188.

Reigeluth, Charles, M. (1983). Instructional Design Theories and Models: An Overview of Their Current Status. New Jersey: Publisher Hilsdale

Romizowski, AZ. (1981). Designing Instructional System. New York: Nichol Publishing Company

Saifullah. (2015). The Internalization of Democratic Values into Education and Their Relevance to Islamic Education Development (Synthetic, Analytic, and Eclectic Implementation of John Dewey's Thoughts). Advanced Science Letters, 21 (7), pp. 2301- 2304, DOI: 10.1166/asl.2015.6257

Saifullah. (2017). Learning by Conscience as a New Paradigm in Education. Advanced Science Letters, 23, (2), pp. 853-856, DOI: 10.1166/asl.2017.7447

Salami, S. (2015). Implementing Neuro Linguistic Programming (NLP) in Changing Students' Behavior: Research Done at Islamic Universities in Aceh. Jurnal Ilmiah Peuradeun, 3(2), 235-256.

Slameto. (1995). Belajar dan Faktor-Faktor Yang Mempengaruhinya. Jakarta: Rineka Cipta.

Snelbecker, E.G. (1974). Learning Theory, Instructional Theory and Psychoeducational Design, New York: Mc Graw Hill.

Soedarsono, FX. (2001). Aplikasi Penelitian Tindakan Kelas. Buku. 2.03 Applied Approach. Jakarta: Proyek Pengembangan Universitas Terbuka. Dirjen Dikti. Departemen Pendidikan Nasional.

Sudjana, N. (1989). Strategi Belajar Mengajar. Jakarta, Rineka Cipta.

Suparman. Atwi. (2001). Desain Instruksional. Jakarta: P2T-UT Dikti Depdikbud. 
Tabrani. ZA \& Masbur, M. (2016). Islamic Perspectives on the Existence of Soul and Its Influence in Human Learning (A Philosophical Analysis of the Classical and Modern Learning Theories). Jurnal Edukasi: Jurnal Bimbingan Konseling, 1(2), 99-112.

Tabrani. ZA. (2014). Islamic Studies dalam Pendekatan Multidisipliner (Suatu Kajian Gradual Menuju Paradigma Global). Jurnal Ilmiah Peuradeun, 2(2), 211-234.

Tabrani. ZA. (2014). Isu-Isu Kritis dalam Pendidikan Islam. Jurnal Ilmiah Islam Futura, 13(2), 250-270

Tilaar, H.A.R. (2003). Perubahan Sosial dan Pendidikan. Jakarta: Grasindo.

Walidin, W. (2016). Informal Education as A Projected Improvement of the Professional Skills of Employees of Organizations. Jurnal Ilmiah Peuradeun, 4(3), 281-294.

Wardiman, J. et al. (2001). Menatap Masa Depan Pendidikan. Jakarta: Gramedia.

Wiriaatmadja, R. (2005). Metode Penelitian Tindakan Kelas. Bandung: Remaja Rosdakarya. 